\title{
TECHNO-ECONOMIC FEASIBILITY STUDY OF AN OFF-GRID HYBRID POWER SYSTEM FOR AN AQUA-TOURISM RESORT IN TERENGGANU, MALAYSIA
}

\author{
MUHAMMAD FAKHRURAZI MD YUNOS, NUR FARIZAN MUNAJAT* AND WAN MARIAM WAN \\ MUDA
}

\author{
School of Ocean Engineering, Universiti Malaysia Terengganu 21030 Kuala Nerus, Terengganu, Malaysia
}

*Corresponding author: nurfarizan@umt.edu.my

\begin{abstract}
This study focused on feasibility analysis of hybrid electrification system for an aqua-tourism resort located remotely from the grid connection in Terengganu. There were four standalone systems used in this study: diesel/PV/biomass/battery, diesel/PV/battery, biomass/diesel/battery, and diesel only. The design and analysis of these systems were done using Hybrid Optimization of Multiple Energy Resources (HOMER) software. The results showed that the diesel/PV/battery system was the optimum solution in terms of net present cost (NPC) and cost of energy (COE). This system comprises $20 \%$ of PV penetration with NPC and COE of USD 57,823 (RM 241, 729.90) and $0.428 \mathrm{USD} / \mathrm{kWh}(1.79 \mathrm{RM} / \mathrm{kWh})$, respectively. Meanwhile, the diesel/PV/biomass/battery system with NPC of USD 65,388 (RM 273, 355.49) and COE of $0.484 \mathrm{USD} / \mathrm{kWh}(2.02 \mathrm{RM} / \mathrm{kWh})$ was found to be the best among all systems in terms of greenhouse emissions. This system was able to reduce almost $70 \%$ of carbon dioxide if compared with diesel only system and about $15 \%$ lower than the diesel/PV/battery system with a renewable energy fraction of $44 \%$.
\end{abstract}

Keywords: Hybrid system, stand-alone, solar PV, biomass, HOMER

\section{Introduction}

Many remote areas in Malaysia are still not connected to main national utility grid (Halabi, et al., 2017). Among the reasons are high cost of installation and distribution of energy to these isolated areas. Diesel generators are often used to fulfill the energy requirements in such areas, such as for lighting, irrigation and pumping (Peerapong \& Limmeechokchai, 2017). However, uncertainty over the cost of generating electricity from diesel engines and negative consequences of burning diesel fuels led to search for more sustainable energy technology (Lau, et al., 2015). In this regard, hybrid system comprising one or more renewable energy sources integrated with diesel engines can be more costeffective and environmentally friendly compared to the grid connections or diesel-only system (Sawle, et al., 2018), (Das, et al., 2017), (Peerapong \& Limmeechokchai, 2017). Furthermore, Malaysia is blessed not only with fossil fuels resources such as oil and gas, but also renewables like solar and biomass, as well as hydro, wind and wave. Malaysia has reasonably high solar radiation $\left(4.8-6.1 \mathrm{kWh} / \mathrm{m}^{2} /\right.$ day $)$ with around four to six hours of sunshine daily in average (Hannan, et al., 2018), (Halabi, et al., 2017), (Lau, et al., 2015). Meanwhile, the availability of biomass in Malaysia is estimated at around 160 million tons per year which include timber, oil palm waste, rice husks, coconut trunk fibers, municipal and sugarcane waste (Sohni, et al., 2018), (Ozturk, et al., 2017), (Malek, et al., 2017). In designing a reliable and efficient hybrid electricity system, aspects like social, institutional and technical need to be considered. HOMER software is one of the tools that has been frequently used by many researchers to analyze both technical and economic feasibility of hybrid electric supply system. Several studies have reported optimum systems of different stand-alone hybrid combinations using HOMER such as PV/ diesel/battery system (Peerapong \& Limmeechokchai, 2017), (Halabi, et al., 2017), (Yilmaz \& Dincer, 2017), (Lau, et al., 2015), PV/biomass/diesel/battery (Islam, et al., 2018), PV/biomass/battery (Eteiba, et al., 2018) and PV/biomass (Shahzad, et al., 2017). The outputs from simulation and optimization using HOMER include net present cost (NPC), the initial cost, the operation cost, cost of energy (COE), renewable fraction, and emissions produced by the hybrid system (Olatomiwa, et al., 2018) (Bahramara, et al., 2016). Terengganu is one the states in Malaysia located in the east coast of Peninsular Malaysia. In addition to petroleum and gas, tourism, fishing, as well as shrimp and fish farming are also major industries in Terengganu. Typically, such tourist attractions centers are developed in near nature and remote areas where electricity from the national grid is unavailable. Therefore, the objective of this paper is to execute the technical and economic feasibility study of the use of solar and/or biomass resources integrated with conventional diesel system for an aqua-tourism resort located $25 \mathrm{~km}$ from the capital city of Terengganu, using the HOMER software tools.

\section{Materials and Methods Site Location}

In this study, the hybrid system was designed for the electrification of an aqua-tourism resort $\left(5^{\circ} 10^{\prime} 32^{\prime \prime} \mathrm{N}\right.$, $103^{\circ} 09^{\prime} 33^{\prime \prime}$ E) which is about $25 \mathrm{~km}$ from Kuala Terengganu district. Figure 1 (a) and (b) show the location of this resort on the map and its top views, respectively. 


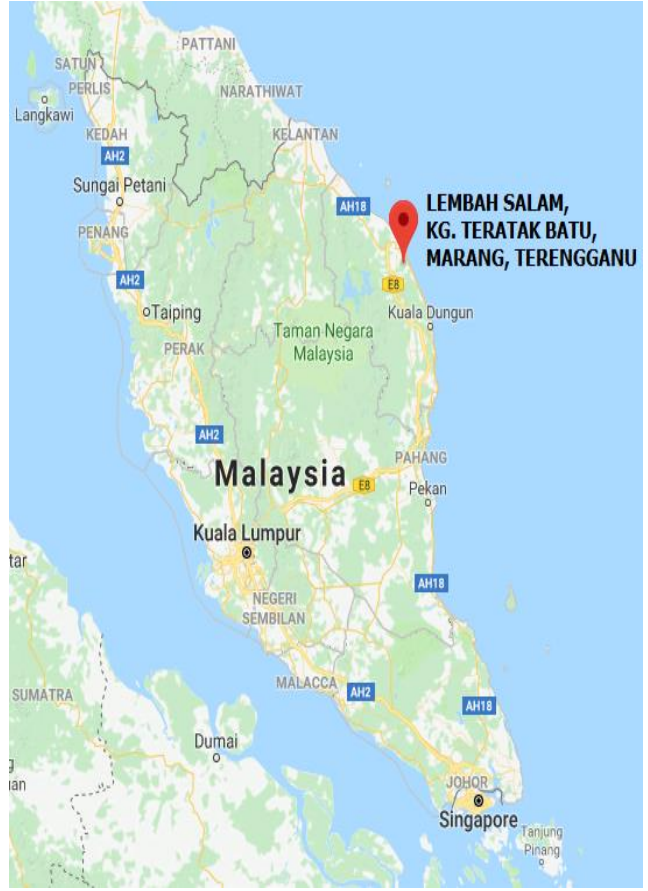

(a)

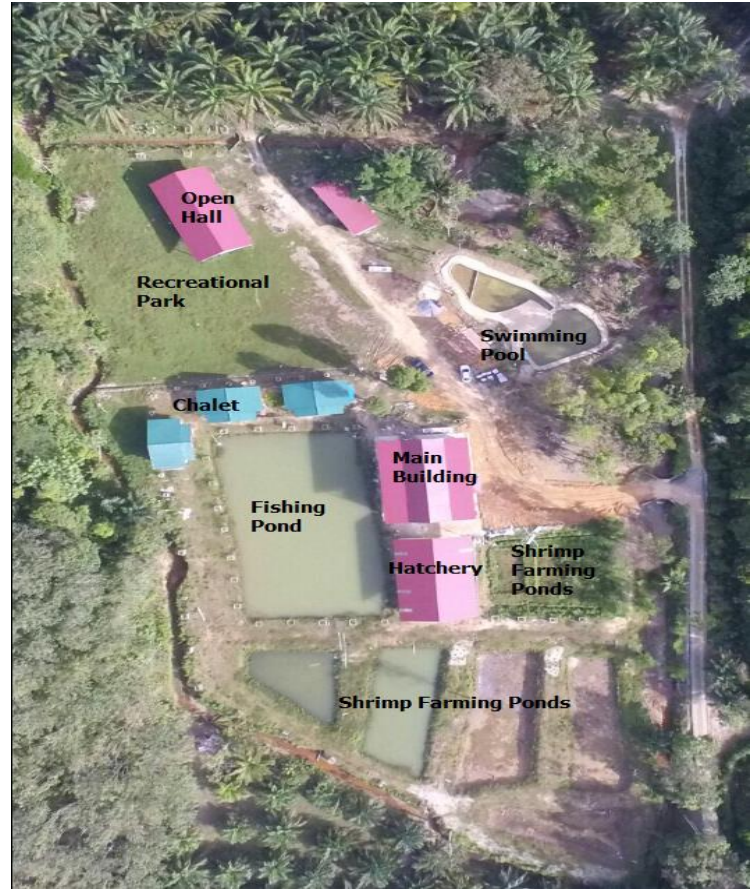

(b)

Figure 1: (a) Location of LS in Peninsular Malaysia [Source: Google map and then edited] (b) Top view of the resort

\section{Site Load Profile}

Load profile considered in this study was based on the usage of electricity at the aqua-tourism resort. The resort consists of six unit of chalets, a dormitory, a hall, public toilets, a swimming pool and a hatchery. The load profile collection started with the identification of the number of electrical appliances used there and the power consumption for each appliance. The components that were taken into account to calculate the load profile were 11 units of 75 watts ceiling fans, 28 units of 40 watts fluorescent lamps, two units of 750 watts air conditioners, a unit of 1.5 kilowatts water filter for swimming pool, a unit of 300 watts water pump, and a unit of 50 watts oxygen blower for hatchery. Load profile data started from 00:00 hours to 24:00 hours which was basically a day period. The load profile was estimated for weekdays and weekend case, considering the number of visitors during weekend is higher than weekdays. Daily consumption of electricity during weekdays was approximately $12.540 \mathrm{kWh}$. While during weekend, daily electricity consumption rose up high to 69.055 kWh. Figure 2 (a) and (b) show the hourly electricity consumption for weekdays and weekend, respectively.

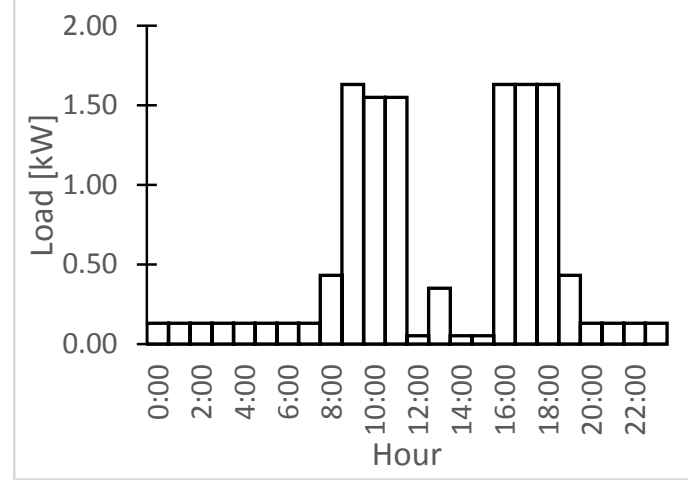

(a)

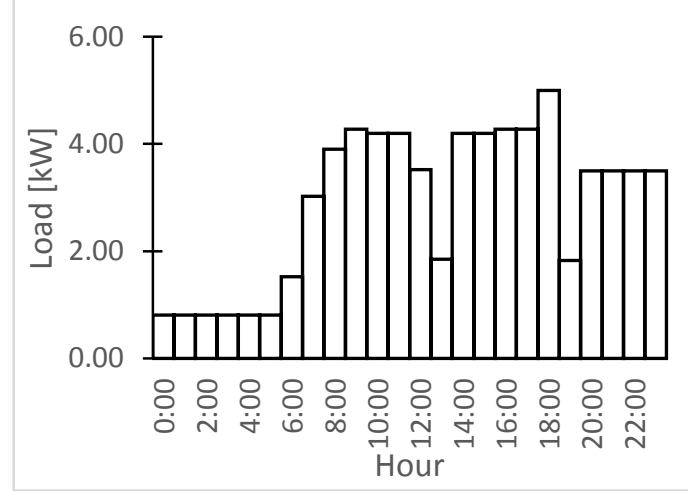

(b)

Figure 2: Total electricity usage in a day during (a) weekdays, and (b) weekend 


\section{Solar Energy}

The solar irradiation data for Kuala Terengganu collected from weather station installed at Universiti Sultan Zainal Abidin (UniSZA) was used in this study. The daily solar radiation data from 2009 until 2015 were averaged to monthly values and are presented in Figure 3. According to this figure, monthly solar radiation for Kuala Terengganu area was in the range of 3.39 to $5.62 \mathrm{kWh} / \mathrm{m}^{2}$ per day, with an annual average of $4.52 \mathrm{kWh} / \mathrm{m}^{2} /$ day.

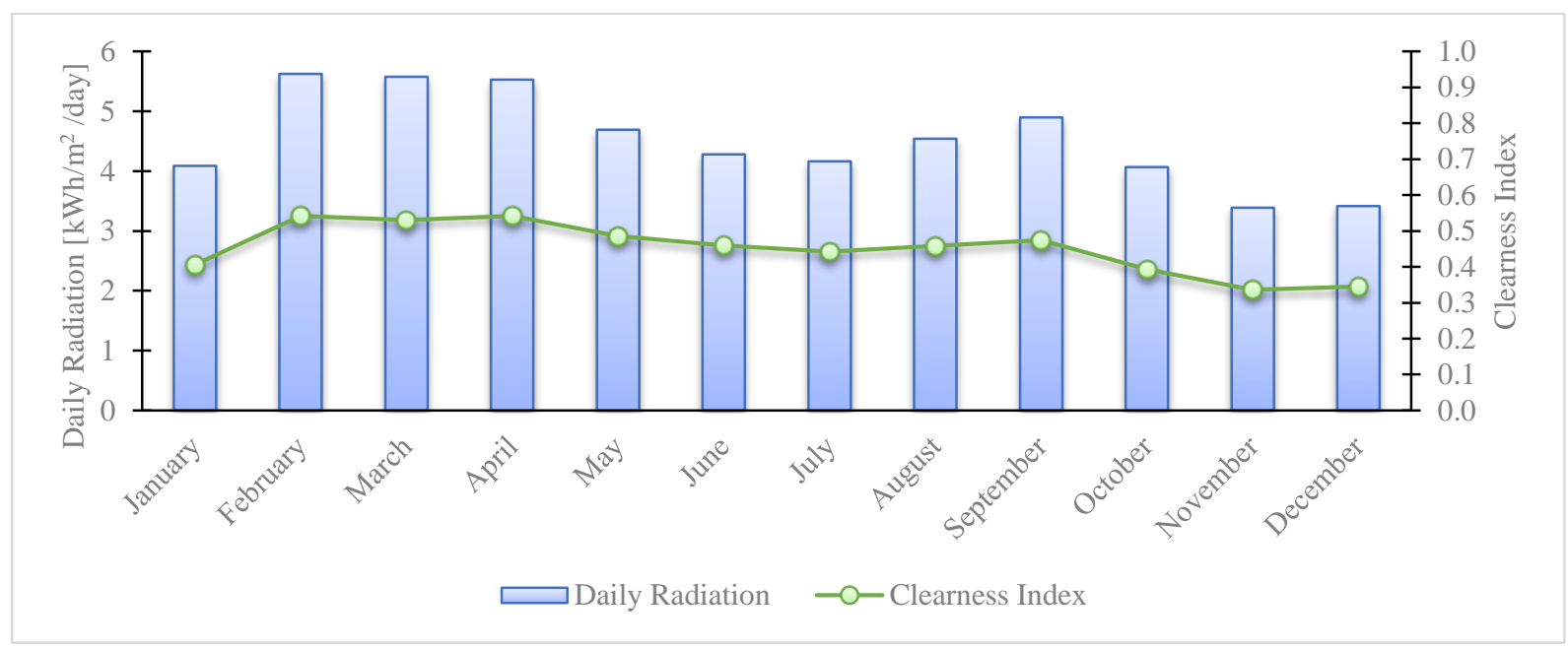

Figure 3: Monthly average daily solar radiation and clearness index in Kuala Terengganu

\section{Biomass Energy}

In this study, biomass was considered in the form of wood pellets. Information on the wood pellet was gathered from Bio Eneco Sdn. Bhd. The wood pellet was used to generate electricity using biomass generator system with its output power estimated at $5 \mathrm{~kW}$. The low heating value for the pellets was $5.5 \mathrm{MJ} / \mathrm{kg}$, and the estimated monthly average of wood pellets required was 0.0864 tons/day. For this study, the wood pellets were

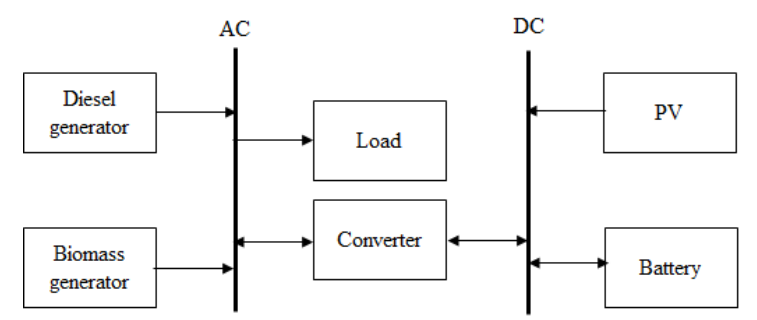

(a)

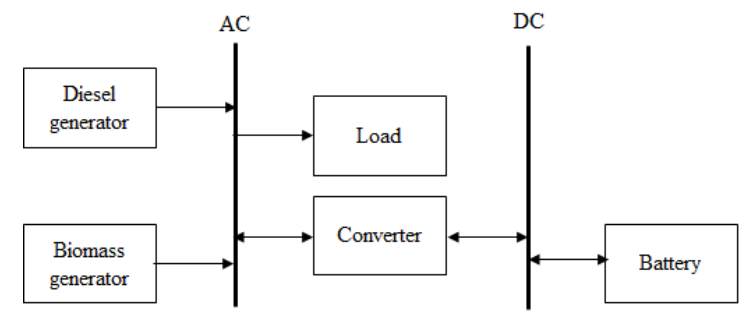

(c) assumed sufficient in supply for the system for 25 years throughout the project lifetime.

\section{System Configuration}

Four system scenarios were considered in this study: $\mathrm{PV} /$ biomass/diesel/battery (PV-BG-DG-B), $\mathrm{PV} /$ diesel/battery (PV-DG-B), biomass/diesel/battery (BG-DG-B), and diesel generator only (DG) as shown in Figure 4 (a), (b), (c) and (d), respectively.

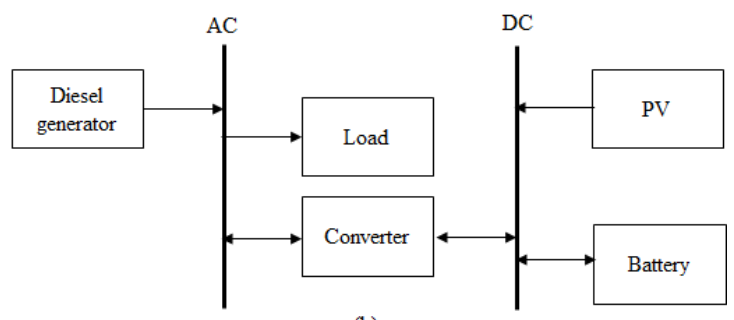

(b)

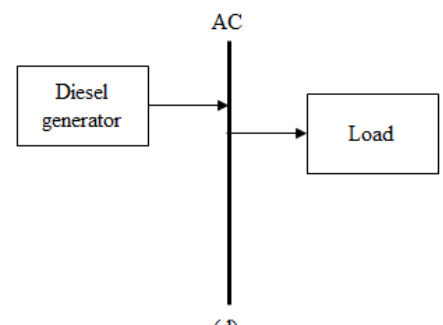

(d)

Figure 4: Configuration of studied system: (a) PV-BG-DG-B, (b) PV-BG -B, (c) BG-DG-B, and (d) DG only 
For these configuration, PV system, biomass generator, and diesel generator were considered as energy resources. Meanwhile, converter and battery were used to maintain the energy flow between direct current (DC) and alternating current (AC) of electrical components, and energy storage for the stand-alone hybrid system, respectively. All the components considered in this studied were based on component specifications (including capital cost, replacement cost and operation and maintenance cost) available in the HOMER PRO Microgrid Analysis Tool 3.8.3 (Pro Edition). The cost details of each component are presented in Table 1.

Table 1: Specifications of input components.

\begin{tabular}{lllll}
\hline $\begin{array}{l}\text { Components of the } \\
\text { system }\end{array}$ & Capital Cost (USD/kW) & $\begin{array}{l}\text { Replacement } \\
\text { Cost (USD/kW) }\end{array}$ & $\begin{array}{l}\text { Operation and maintenance } \\
\text { Cost }\end{array}$ & Lifetime \\
\hline Solar PV & 3000.00 & 3000.00 & 10.00 USD/year & 25 years \\
Biomass Generator & 3000.00 & 1250.00 & 0.10 USD/hour & 20,000 hours \\
Diesel generator & 500.00 & 500.00 & 0.03 USD/hour & 15,000 hours \\
Battery (Lead Acid) & 300.00 & 300.00 & 10.00 USD/year & 10 years \\
Converter & 300.00 & 300.00 & 0 & 15 years \\
\hline
\end{tabular}

The simulation was executed by considering a 25 years project lifetime with nominal discount rate of $8.0 \%$ and expected inflation rate of $2.0 \%$ (Hossain, et al., 2017). The average price for the wood pellet is USD 115.95 per ton and diesel price is at USD 0.56 per litre.

The detailed economic model used by HOMER to calculate the COE and NPC can be retrieved from (Hossain, et al., 2017) and (Bhattacharjee \& Dey, 2014).

\section{Results and Discussion}

The HOMER simulation estimates the cost as well as the feasibility of hybridized systems over the year with a list of system configurations. The capacities of the system configuration then are sorted based on the lowest NPC and COE. The cost analysis and component sizes for all systems in this study are shown in Figure 5 and 6 . It can be observed that the PV-DG-B system offered the lowest NPC and COE of USD 57, 823 (RM 241, 729.90) and $0.428 \mathrm{USD} / \mathrm{kWh}(1.79 \mathrm{RM} / \mathrm{kWh})$, respectively, with $22 \%$ of renewable sources fraction. This system consisted of $3 \mathrm{~kW}$ PV panel, $6 \mathrm{~kW}$ diesel generator, six batteries (each of $83.4 \mathrm{Ah}$ ) and $3 \mathrm{~kW}$ converter. The second best combination was PV-BG-DG-B followed by BG-DG-B and DG only. This means that the electricity generation cost from biomass was higher than PV panels but still cheaper compared to DG only system. The values of COE and NPC for DG only being higher than the other hybrid systems were attributed to its higher operation hour for the same load. Furthermore, the lifetime of diesel generator as listed in Table 1 is the lowest compared the other hybrid system components.

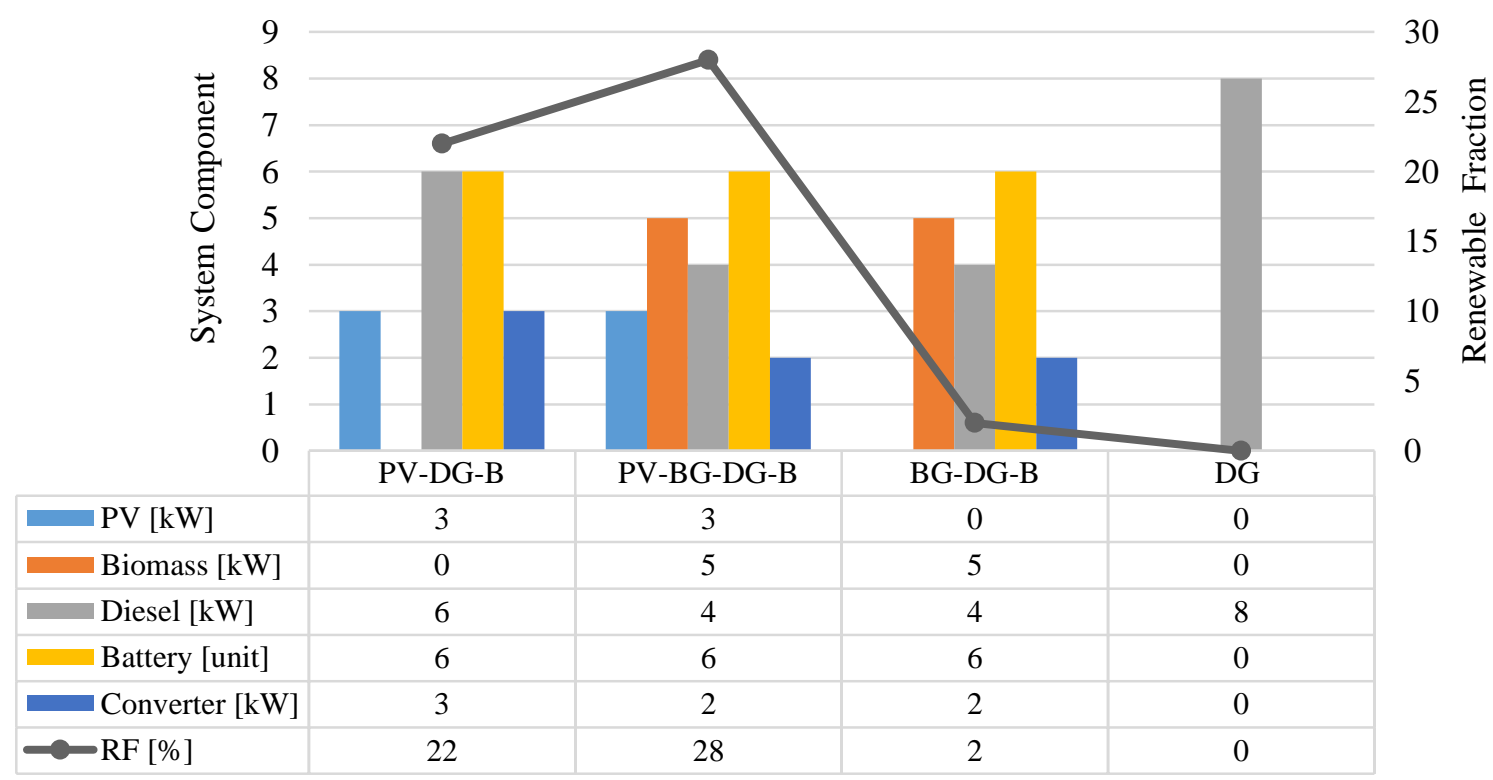

Figure 5: Component sizes for the studied system scenarios 


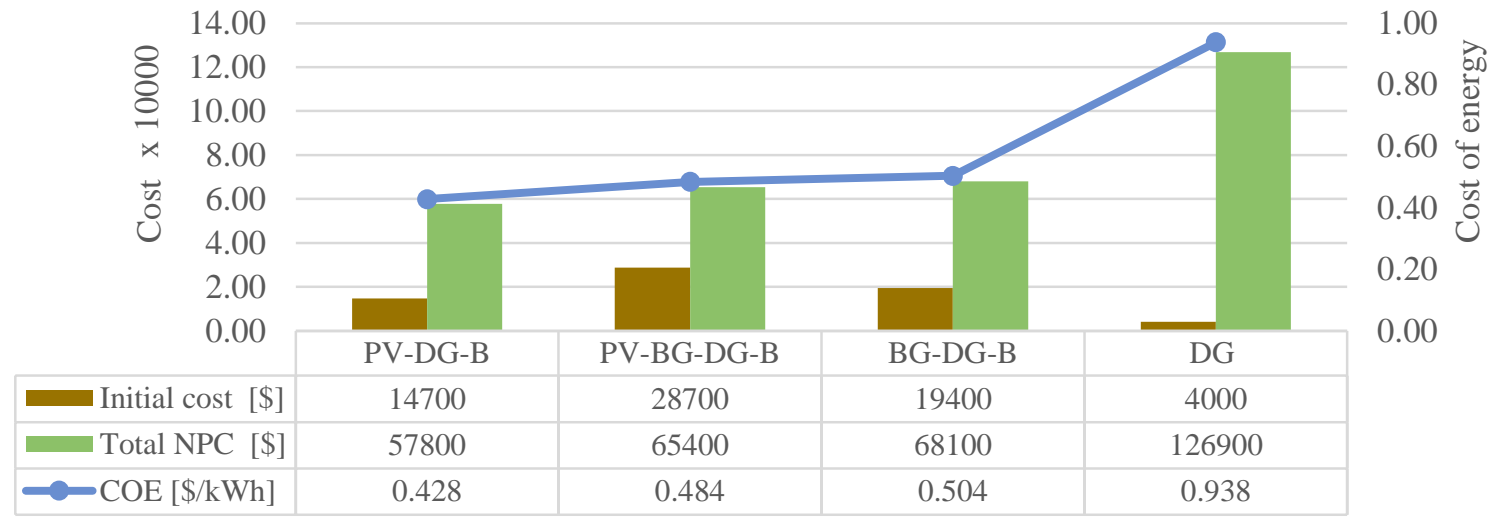

Figure 6: Cost summary for the studied system scenarios

Details related to the monthly average amount of electricity generated by each component for different system configurations are shown in Figure 7. It is evident that regardless of configurations of the system, most of the electricity produced throughout the year to meet the load (tabulated in Figure 2) came from DG. Of the total primary energy requirement of the resort, the diesel generator produced $8,136 \mathrm{kWh} / \mathrm{yr}(67 \%), 7,547 \mathrm{kWh} / \mathrm{yr}$
(63\%) and 10,198 kWh/yr (93\%) for PV-DG-B, PV-BGDG-B and BG-DG-B system, respectively. For systems with solar PV, the electricity generated by the panel was $33 \%$ of the energy that was $3,959 \mathrm{~kW} / \mathrm{hr}$. Meanwhile, the biomass generator produced only $415 \mathrm{kWh} / \mathrm{yr}(3 \%)$ for PV-BG-DG-B and $776 \mathrm{kWh} / \mathrm{yr}(7 \%)$ for BG-DG-B system. This corresponds to the respective amount of biomass generator capacity as listed in Figure 5.

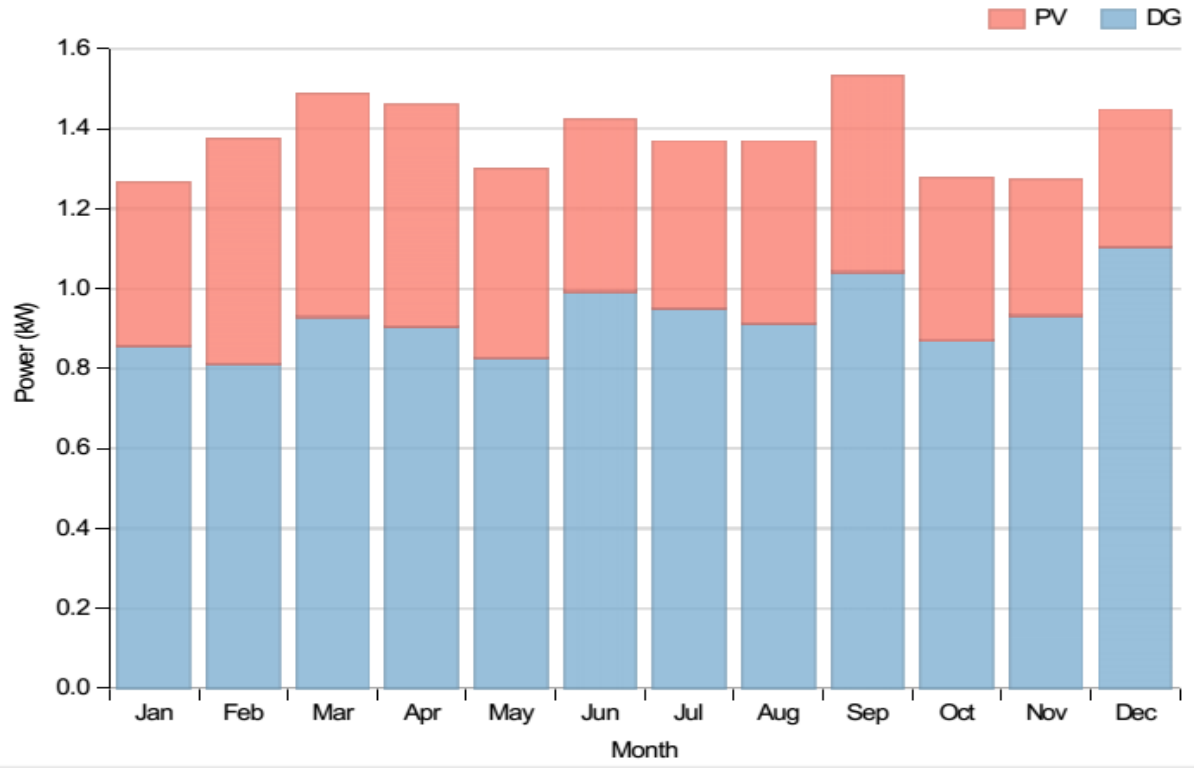

(a) 


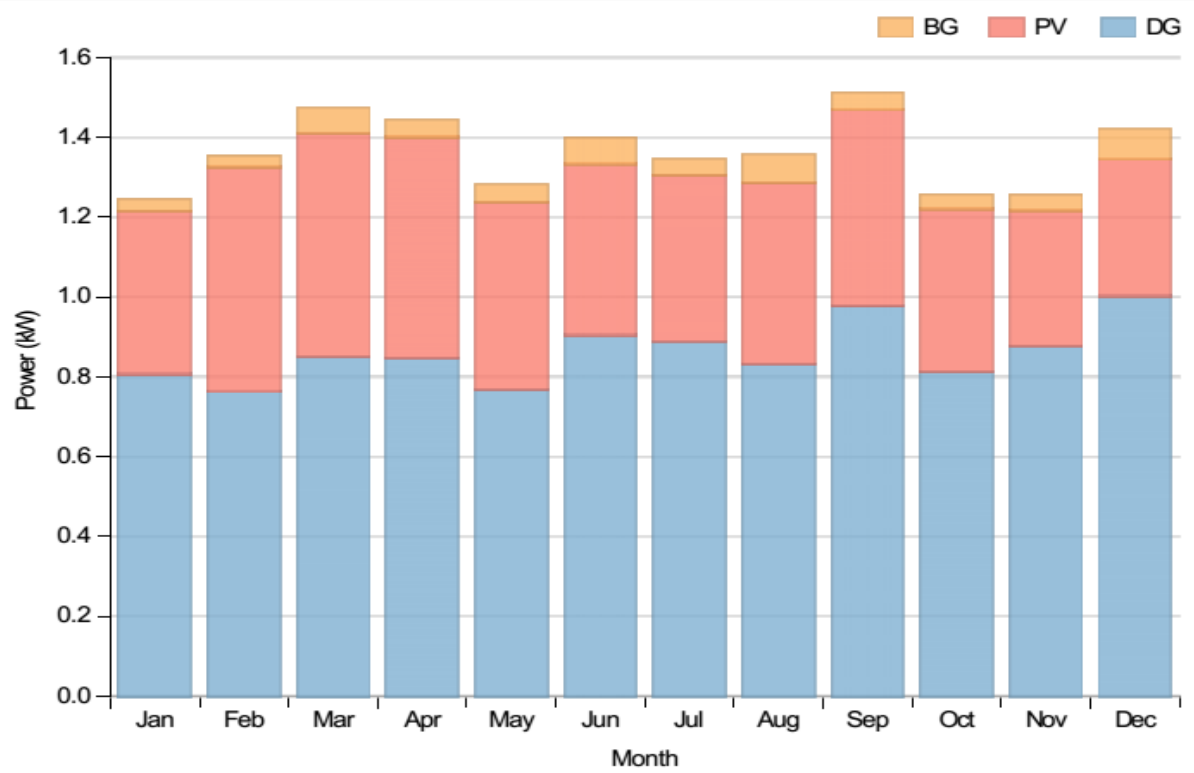

(b)

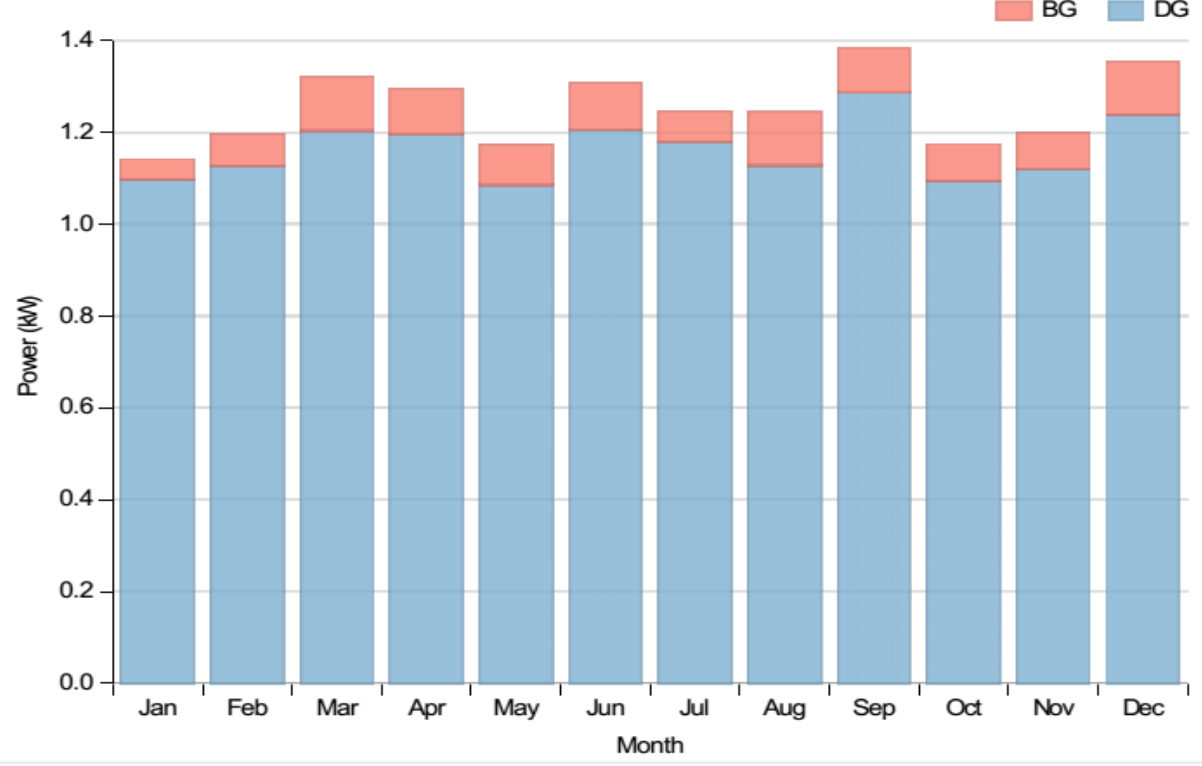

(c)

Figure 7: Monthly average amount of electricity generated by each component for (a) PV-DG-B, (b) PVBG-DG-B and (c) BG-DG-B system

Emissions of carbon dioxide $\left(\mathrm{CO}_{2}\right)$, carbon monoxide (CO), unburned hydrocarbons (UHC), sulphur oxide $\left(\mathrm{SO}_{2}\right)$, nitrogen oxide $\left(\mathrm{NO}_{\mathrm{x}}\right)$ and particulate matter $(\mathrm{PM})$ for various systems considered in this study are presented in Figure 7. It can be seen here that the annual rate of the addition of this GHG emission into the local atmosphere was significantly decreased even with only a small increase of renewable fractions in the integrated system (Figure 5). Taking $\mathrm{CO}_{2}$ as an example, the diesel only system produced as high as $24,175 \mathrm{~kg}$ per year. These values can be reduced to 7140,8244 and 9533 $\mathrm{kg} / \mathrm{year}$, if the electricity power source from diesel only system is converted to either PV-BG-DG-B, PV-DG-B or BG-DG-B system, respectively. 


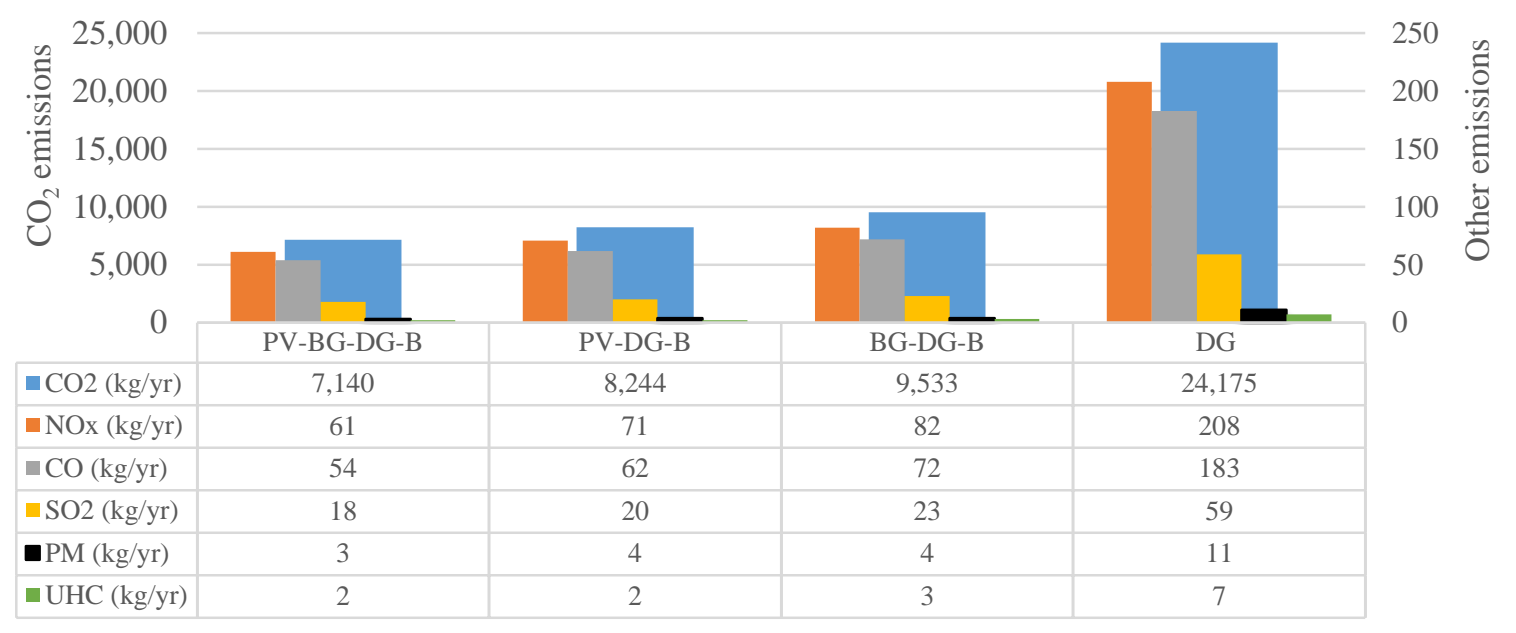

Figure 7: Comparative $\mathrm{CO}_{2}$ and other emissions to supply energy in the studied system

\section{Conclusion}

This study presents a techno-economic evaluation of various off-grid hybrid configurations for supplying electricity to an aqua-tourism resort in Terengganu, Malaysia. Different system were analyzed in HOMER and simulation results for PV-BG-DG-B, PV-DG-B, BG-DG-B and DG-only system were compared. From the economic perspective, the PV-DG-B was the best option for powering the resort with the lowest COE (\$ 57 823/ RM 241,729.90) and NPC (\$ 0.428/ RM 1.79 per $\mathrm{kWh}$ ) followed by PV-BG-DG-B, BG-DG-B and DGonly system. The reduction between 46 to $54 \%$ of both NPC and COE can be obtained, if the diesel-only system is replaced by hybrid systems. Meanwhile, the addition of renewable sources by 2 to $28 \%$ to the diesel system could reduce GHG emissions by 70 to $72 \%$. This indicates that, the addition of RE sources and batteries to the diesel only system can be regarded as a good investment in term of fuel saving and emission reduction.

\section{Acknowledgements}

Support from Universiti Malaysia Terengganu is gratefully acknowledged. The authors would also like to thank Universiti Sultan Zainal Abidin for the meteorological data and Bio Eneco Sdn. Bhd. for information regarding biomass pellets.

\section{References}

Bahramara, S., Moghaddam, M., \& Haghifam, M. (2016). Optimal planning of hybrid renewable energy systems using HOMER: A review. Renewable and Sustainable Energy Reviews, 62, 609 $-620$.
Bhattacharjee, S. \& Dey, A. (2014). Techno-economic performance evaluation of grid integrated PVbiomass hybrid power generation for rice mill. Sustainable Energy Technologies and Assessments, 7, pp. $6-16$.

Das, H., Tan, C., Yatim, A., \& Lau, K. (2017). Feasibility analysis of hybrid photovoltaic/battery/fuel cell energy system for an indigenous residence in East Malaysia. Renewable and Sustainable Energy Reviews, 76, 1332-1347.

Eteiba, M., Barakat, S., Samy, M., \& Wahba, W. (2018). Optimization of an off-grid PV/Biomass hybrid system with different battery technologies. Sustainable Cities and Society, 40, 713 - 727.

Halabi, L., Mekhilef, S., Olatomiwa, L., \& Hazelton, J. (2017). Performance analysis of hybrid PV/diesel/battery system using HOMER: A case study Sabah, Malaysia. Energy Conversion and Management, 144, 322 - 339.

Hannan, M., Begum, R., Abdolrasol, M., Lipu, M., Mohamed, A., \& Rashidd, M. (2018). Review of baseline studies on energy policies and indicators in Malaysia for. Renewable and Sustainable Energy Reviews, 94, 551 - 564.

Hossain, M., Mekhilef, S., \& Olatomiwa, L. (2017). Performance evaluation of a stand-alone PV-winddiesel-battery hybrid system feasible for a large resort center in South China Sea, Malaysia. Sustainable Cities and Society, 28, 358 - 366.

Islam, M., Akhter, R., \& Rahman, M. (2018). A thorough investigation on hybrid application of biomass gasifier and PV resources to meet energy needs for a northern rural off-grid region of 
Bangladesh: A potential solution to replicate in rural off-grid areas or not? Energy, 145, 338 - 355.

Lau, K., Tan, C., \& Yatim, A. (2015). Photovoltaic systems for Malaysian islands: Effects of interest rates, diesel prices and load sizes. Energy, 83, 204 216.

Lau, K., Yousof, M., Arshad, S., Anwari, M., \& Yatim, A. (2010). Performance analysis of hybrid photovoltaic/diesel energy system under. Energy, 35, $3245-3255$.

Malek, A., Hasanuzzaman, M., Rahim, N., \& Turki, Y. (2017). Techno-economic analysis and environmental impact assessment of a $10 \mathrm{MW}$ biomass-based power plant in Malaysia. Journal of Cleaner Production, 141, 502 - 513.

Nandi, S., \& Ghosh, H. (2010). Prospect of wind-PVbattery hybrid power system as an alternative to grid extension in Bangladesh. Energy, 35, 3040e3047.

Olatomiwa, L., Blanchard, R., Mekhlief, S., \& Akinyele, D. (2018). Hybrid renewable energy supply for rural healthcare facilities: An approach to quality healthcare delivery. Sustainable Energy Technologies and Assessments, 30, 121 - 138.

Ozturk, M., Saba, N., Altay, V., Iqbal, R., Hakeem, K., Jawaid, M., \& Ibrahim, F. (2017). Biomass and bioenergy: An overview of the development potential in Turkey and Malaysia. Renewable and Sustainable Energy Reviews, 79, 1285 - 1302.

Peerapong, P., \& Limmeechokchai, B. (2017). Optimal electricity development by increasing solar resources in diesel-based micro grid of island society in Thailand. Energy Reports, 3, 1 - 13.

Sawle, Y., Gupta, S., \& Bohre, A. (2018). Review of hybrid renewable energy systems with comparative analysis of off-grid hybrid system. Renewable and Sustainable Energy Reviews, 81, 2217 - 2235.

Shahzad, M., Zahid, A., Rashid, T., Rehan, M., Ali, M., \& Ahmad, M. (2017). Techno-economic feasibility analysis of a solar-biomass off grid system for the electrification of remote rural areas in Pakistan using HOMER software. Renewable Energy, 106, 264 273.

Sohni, S., Norulaini, N., Hashim, R., Khan, S., Fadhullah, W., \& Omar, A. (2018). Physicochemical characterization of Malaysian crop and agroindustrial biomass residues as renewable energy resources. Industrial Crops and Products, 111, 642 650 .
Yilmaz, S., \& Dincer, F. (2017). Optimal design of hybrid PV-Diesel-Battery systems for isolated lands: A case study for Kilis, Turkey. Renewable and Sustainable Energy Reviews, 77, 344 - 352. 